А. А. ЛУКАШАНЕЦ* Претходно саопштење са научног састанка Центр исследований белорусской культуры, Примљен: 12. 12. 2016. языка и литературы Национальной академии Прихваћен: 10. 02. 2017. наук Беларуси, Республика Беларусь, Минск

\title{
ОРГАНИЗАЦИЯ ХУ МЕЖДУНАРОДНОГО СЬЕЗДА СЛАВИСТОВ В МИНСКЕ: ИТОГИ И ПЕРСПЕКТИВЫ МИРОВОЙ СЛАВИСТИКИ
}

20-27 августа 2013 года в Минске (Республика Беларусь) состоялся XV Международный съезд славистов - крупный научный форум, на котором обсуждались проблемы исторического развития и исследования славянских языков, литератур, культур и фольклора.

В Республике Беларусь международный съезд славистов проводился впервые и стал важным научным и культурным событием в жизни страны. Международные съезды славистов проводятся каждые пять лет по очереди в славянских странах, начиная с 1929 года. Принятое в 2008 году в Охриде (Республика Македония) решение Международного комитета славистов о проведении XV Международного съезда славистов в Беларуси не является случайным. Этому способствовал целый ряд различных факторов.

\section{I. Основными предпосылками проведения XV MCC в Минске являются историко-культурные и научные}

Предпосылки исторического плана базируются на следующем.

1. Республика Беларусь - славянская страна, подтвердившая свою подлинную независимость только в конце XX века. Вместе с тем история белорусской государственности насчитывает целое тысячелетие. Первыми государственными объединениями на территории современной Беларуси являются Полоцкое и Туровское княжества, появившиеся еще в X веке пер-

\footnotetext{
*alukashanets@tut.by
} 
вого тысячеления и игравшие важную роль в политической и культурной жизни восточных славян. Фактически государствообразующим являлся белорусский этнос в Великом Княжестве Литовском - крупнейшем многонациональном государстве средневековой Европы. Как и многие другие славянские народы, белорусы во второй половине II тысячелетия утратили свою государственность и вынуждены были жить, сохранять и развивать свои национальные языки и культуры в составе многонациональных империй. Но именно сохранение национальной культуры, формирование нового белорусского литературно-письменного языка, развитие национальной литературы и укрепление национального самосознания позволило белорусам в начале XX века частично восстановить свою государственность, сначала в 1918 году в форме Белорусской Народной Республики (БНР), затем, позднее, в форме Белорусской Советской Социалистической Республики (БССР) в составе Советского Союза (СССР). И только в конце XX века белорусы, как и ряд других славянских народов, получили уникальною возможность реализовать действительную, признанную мировым сообществом, независимость.

2. Письменная традиция на белорусских землях возникла в связи с принятием христианства и опиралась первоначально на церковнославянскую и древнерусскую книжность. Самостоятельный белорусский (старобелорусский) литературно-письменный язык существует с XIV века. Он выполнял функции официального языка в Великом Княжестве Литовском, на нем активно создавались литературные произведения различных жанров. На старобелорусском языке создана первая Конституция Великого Княжества Литовского - Статут Великого Княжества Литовского. На старобелорусском языке печатал свои книги белорусский и восточнославянский первопечатник Франциск Скорина.

3. Беларусь имеет уникальный исторический опыт сосуществования славянских языков, литератур и культур и их взаимодействия с разными неславянскими языками, литературами и культурами в Великом Княжестве Литовском. Специфика языкового развития Беларуси в XIX-XX веках демонстрирует опыт формирования и становления норм национального языка в условиях близкородственного славянского дву- и многоязычия, сосуществования двух графических систем. В начале XXI века белорусский язык является единственным славянским языком, который развивается и функционирует в условиях государственного близкородственного двуязычия. Особенностью нынешнего состояния государственного белорусского языка является параллельное функционирование в коммуникативном пространстве двух литературно-письменных вариантов. Также своеобразным парадоксом современной языковой ситуации в Беларуси является, с одной стороны, недостаточная востребованность государственного белорусского языка как реального средства общения в большинстве официальных сфер коммуникации и, с другой стороны, его активное проникновение в новые сферы коммуникации (интернет-коммуникация, конфессиональная сфера). Все это приобретает особую актуальность для современной славистики в плане прогно- 
зирования перспектив развития и функционирования славянских языков в глобальном, стремительно развивающемся, информационном обществе.

Научные предпосылки проведения XV Международного съезда славистов в Минске обусловлены уровнем развития национальной славистики, вкладом белорусских славистов в развитие мировой славистики, а также уровнем национального языкознания, литературоведения, фольклористики и культурологии. В этом плане значимыми наиболее являются следующие аспекты.

1. Весомый вклад белорусских исследователей в становление и развитие основных направлений мировой славистики. Так, по общему признанию белорусский археолог, фольклорист, этнограф и диалектолог Зориан Даленга-Ходаковский (Адам Чарноцкий) - является одним из основателей славянской фольклористики. Уже в начале XIX века он впервые в славянском языкознании выделил белорусский язык из других славянских языков, определил некоторые его фонетические, морфологические и лексические особенности, ареал распространения. Также он первым среди славянских ученых обратил внимание на исторические памятники белорусского языка (Аксамитов 1994). Фольклорный архив 3. Даленго-Ходаковского параллельно с собранием серба Вука Караджича считается первым и наиболее богатым собранием фольклора славянских народов по количеству записей и по величине охваченной территории.

Во второй половине XIX века различные аспекты белорусской истории, культуры, языка и литературы в славистическом аспекте рассматривали И. Григорович, М. Довнар-Запольский, Е. Карский, И. Носович, Е. Романов и др.

2. Формирование национального языкознаниия и белорусской славистики. Формирование нового литературно-письменного белорусского языка в XIX веке, бурное развитие белорусской литературы и активная собирательская деятельность способствовали формированию к началу XX века научной белорусистики и белорусской национальной славистики как самостоятельных ответвлений лингвистической науки того времени. Огромная заслуга в этом принадлежит в первую очередь академику Евфимию Фёдоровичу Карскому (1861-1931) - выдающемуся белорусскому филологу, языковеду и слависту, создателю белорусского научного языкознания, что способствовало, во-первых, укреплению статуса белорусского языка как самостоятельного славянского языка, а, во-вторых, вовлечению белорусского языкового, литературного и фольклорного материала в сферу славистических исследований.

Его выдающийся труд „Беларусы” (в 3-х томах, 7-ми книгах) посвящен исследованию системы белорусского языка, истории его развития, исследованию памятников белорусской письменности и т.д. По мнению профессора М.Г. Булахова, это трехтомное исследование академика Е.Ф. Карского „занимает исключительное место как в истории белорусской, так и вообще славянской филологии” (Булахов 1994: 92), а „по глубине научного освещения, широте охвата фактов, культурно-общественнной значимости исследование не имело на то время равных себе филологических трудов ни в одной стране" (Булахов 1994: 91). 
Значение трудов Е.Ф. Карского для белорусистики и славистики заключается в:

- $\quad$ научном закреплении статуса белорусского языка как отдельного славянского языка с развитой системой словообразования, словоизменения и синтаксиса;

- осуществлении первого опыта последовательного, академического научного описания различных уровней системы белорусского языка;

- формировании лингвистических предпосылок для выработки литературных норм и введения белорусского языка в официальные сферы общения и образовательную практику;

- создании теоретической базы для подготовки учебной и справочной литературы для обеспечения нужд языковой практики;

- системном исследовании памятников белорусской письменности и белорусского фольклора;

- введении белорусского языка, литературы и фольклора в славянское языковое и культурное пространство.

В начале XX века развитие национальной славистики связано со становлением белорусской государственности, основанием Белорусского государственного университета и Института белорусской культуры, а позднее - Национальной академии наук Беларуси и Института языкознания имени Якуба Коласа. Развитие белорусской лингвистической славистики в этот период связано с именами таких известных белорусских лингвистов-славистов, как П.А. Бузук, И.В. Волк-Леванович и др. Во второй половине XX века вопросами славистики активно занимались лингвисты М.Г. Булахов, А.Е. Супрун, Л.М. Шакун, В.В. Мартынов, Н.В. Бирилло, А.И. Журавский, Н.Б. Мечковская, Г.А. Цыхун, Б.Ю. Норман и др. Также значительный вклад в развитие славистики в $\mathrm{XX}$ веке внесли белорусские литературоведы, фольклористы и культурологи.

3. Активное участие в белорусских славистов в международных съездах славистов. На I Международном съезде славистов (Прага, 1929) с докладом „Лингвистическая география как вспомогательный метод при изучении истории языка" выступил профессор Пётр Афанасьевич Бузук. Начиная с IV MCC (Москва, 1958) участие белорусских славистов в этих научных форумах становится постоянным. С этого же времени начинает свою деятельность и национальный Белорусский комитет славистов. Особенно заметным становится участие белорусских ученых (лингвистов, литературоведов и фольклористов) в съездах славистов в конце XX - начале XXI века.

4. Подготовка и издание крупных фундаментальных трудов по белорусистике и славистике. Международному авторитету белорусской филологической науки, в том числе славистики, в немалой степени способствовали подготовка и издание во второй половине XX века фундаментальных трудов по языкознанию, литературоведению и фольклору, таких, как, например, академические словари, в том числе толковые и переводные двуязычные, и грамматики белорусского языка, исторический и этимологический словари белорусского языка, цикл диалектных словарей и атласов, монографические 
исследования по белорусскому языку, литературе и фольклору, издание собраний сочинений классиков белорусской литературы и собраний белорусского фольклора, подготовка национального корпуса белорусского языка и др. Все это способствовало не только активному участию белорусских ученых с съездах славистов и широкой представленности белорусской проблематики в тематике съездов, но и пристальному вниманию к белорусской составляющей со стороны зарубежных славистов, в том числе из неславянских стран.

5. Участие белорусских славистов в работе комиссий при МКС и разработке крупных славистических проектов. Это является свидетельством того, что в стране развиваются практически все основные направления славистических исследований, в том числе и самых новых. В этом отношении особо следует отметить многолетнюю плодотворную работу Комиссии Общеславянского лингвистического атласа, в работе которой участвуют ученые всех славянских стран, в том числе и Беларуси. Примером плодотворного славянского научного сотрудничества можно также считать работу Комиссии по славянскому словообразованию. Результатом двадцатилетней деятельности этой комиссии являются проведение семнадцати международных научных конференций, посвященных актуальным проблемам славянского словообразования, и шестнадцать сборников научных статей, изданных по итогам этих конференций. В работе этой комиссии с первого дня ее существования активное участие принимают белорусские дериватологи. Члены Комиссии по славянскому словообразованию подготовили ряд теоретических разделов, а также очерки по словообразованию славянских языков для уникального международного пятитомного словообразовательного проекта "Word-Formation. An International Handbook of the Languages of Europe" (Berlin/Boston, 2015 - 2016).

Белорусские ученые принимали активное участие в выполнении ряда других славистических проектов современности, таких, как „Najnowsze dzieje języków słowiańskich” и „Komparacja współczesnych języków słowiańskich” и др.

Все это в немалой степени предопределило решение Международного комитета славистов о проведении XV Международного съезда славистов в 2013 году в Минске.

\section{II. Основные итоги съезда славистов в Минске}

1. В соответствии с определенными Международным комитетом славистов квотами на участие в съезде было подано свыше 800 заявок. В программу съезда в результате было включено 594 доклада. С докладами на съезде выступили 523 ученых из 34 стран мира (Австрии, Болгарии, Беларуси, Бельгии, Боснии и Герцеговины, Венгрии, Великобритании, Германии, Израиля, Испании, Италии, Казахстана, Канады, Литвы, Македонии, Норвегии, Нидерландов, Польши, России, Румынии, Сербии, Словакии, Словении, США, Украины, Финляндии, Франции, Хорватии, Черногории, Чехии, Швейцарии, Швеции, Эстонии, Японии). Некоторые участники выступили с двумя докладами - на секционных заседаниях и на заседаниях тематических блоков. 
На съезде работали 16 секций, два круглых стола и 25 тематических блоков. Во время съезда работала книжная выставка, на которой была представлена важнейшая славистическая литература, изданная в различных странах за последние пять лет. Также для участников съезда была предложена обширная культурная программа, что позволило им ознакомиться с историей и культурой Беларуси во время посещений музеев и выставок, а также экскурсий в такие исторические центры страны, как Полоцк, Несвиж, Мир и др.

Работа XV Международного съезда славистов широко освещалась в средствах массовой информации, что также свидетельствовало о важности этого научного форума и интересе научной общественности Минска и Беларуси к проблемам современной славистики.

С пленарными докладами в день открытия съезда выступили:

1. Смулкова Эльжбета (Польша): „Язык как предмет и фактор интеграции".

2. МакМиллин Арнольд (Великобритания): „Язык, история и пространство в белорусской литературе".

3. Ц Цыхун Геннадий (Беларусь): „Аспекты славянской ареальной лингвистики".

К началу съезда были подготовлены и изданы программа съезда и тезисы докладов (XV МЗС Праграма 2013; XV МЗС Тезисы-1 2013; XV МЗС Тезисы-2 2013), а также другая литература, специально приуроченная к XV Международному съезду славистов (Булахов 2013; XV МЗС Беларуская 2013; XV МЗС Замежная 2013). Кроме того, в соответствии с существующей традицией к началу съезда были опубликованы в полном объеме доклады всех участников съезда.

Все это позволило максимально полно продемонстрировать на съезде основные достижения мировой славистики за последние пять лет, прошедшие со времени проведения предыдущего съезда славистов в 2008 году.

2. Проведение съезда показало, что в XXI веке:

- славистика сохраняет свое значение как самостоятельное ответвление гуманитарной науки;

- $\quad$ в мире усиливается интерес к славянскому миру, языкам, литературам и культурам славянских народов;

- сохраняют актуальность многие традиционные проблемы славистики;

- $\quad$ существует необходимость сохранения и поддержания славянской идентичности, а также усиления научного сотрудничества;

- $\quad$ международные съезды славистов остаются важнейшим фактором поддержания и развития славистики в мире, определяют ее основные направления.

3. Тематика и программа XV Международного съезда славистов засвидетельствовали, что в XXI веке новые реалии современности ставят перед славистикой новые задачи и проблемы. 
Во-первых, очевидным становится существенное расширение географии участников этих международных славистических форумов. Это, с одной стороны, свидетельствует о сохраняющемся и усиливающемся внимании к славянскому миру, славянским языкам, литературам и культурам. С другой стороны, названная тенденция позволяет рассматривать вопросы современного развития отдельных славянских языков, литератур и культур на широком славянском и неславянском фоне и в то же время актуализирует задачу поддержания и сохранения именно славяноведческой компаративистики, прежде всего лингвистической.

Во-вторых, на рубеже тысячелетий очевидным становится феномен значительного расширения славянского пространства, что отчетливо проявляется в двух аспектах:

- $\quad$ интенсивном расширении славянского присутствия в неславянских странах, что ставит на порядок дня изучение особенностей включения славянских языков, литератур и культур в неславянскую культурную среду, а также проблемы их сохранения в этой среде. Кроме того, именно этот аспект славянского расширения способствует включению в сферу славистики проблем изучения славянских языков, литератур и культур как иностранных, а также создает новые социолингвистические условия для развития и функционирования отдельных славянских языков, имеющих устоявшуюся литературную традицию, например, белорусского, украинского, словацкого, словенского и др. Кроме того, появление на постсоветском пространстве новых государств поставило славянский русский язык в новые условия функционирования в славянском и неславянском языковом и культурном контексте, например, в Украине, Беларуси, Латвии, Литве и т.д. Наконец, изменившиеся социально-политические условия жизни славянских стран и народов коснулись места и роли отдельных славянских языков в общем славянском коммуникативном пространстве, например, русского языка как средства международного общения в славянских странах.

Названные обстоятельства самым непосредственным образом влияют на диапазон и приоритеты славистических исследований в XXI веке. Так, для современной славистики, в том числе и для международных съездов славистов, особенно актуальными становятся проблемы:

a) расширения круга славистической проблематики (славянской социолингвистики, социокультурологии, социолитературоведения);

б) включения славянских языков, литератур и культур в неславянскую среду;

в) актуализации дидактических аспектов славистики;

г) сохранения и повышения внутриславянской языковой и культурной компетенции;

д) расширения фактологической базы славистических исследований (славянская эмигрантология); 
е) развития междисциплинарных славистических иссследований;

ж) формирования новых направлении славистики (компьютерной славистики, корпусной славистики, славянского интернет-дискурса) и т.д.

В-третьих, влияние внешней культурно-языковой экспансии на развитие славянских языков, литератур и культур, а также на современную славистику. В языковой сфере эта экспансия проявляется в так называемой тенденции к интернационализации - беспрецедентном давлении английского языка и активном пополнении лексиконов всех славянских языков большим количеством иноязычных заимствований, что негативно сказывается на реализации собственных внутриязыковых номинативных возможностей славянских языков, в том числе словообразовательных, и ведет к нивелированию национальной специфики каждого славянского языка.

Внешнее языковое давление (тенденция к интернационализации) на славянские языки и культуры проявляется в настоящее время и в активном проникновении международных языков (главным образом, английского) в ряд коммуникативных сфер внутринационального общения (науку, бизнес, спорт, культуру, интернет-коммуникацию, образование и т.д.). Этот аспект интернационализации и глобализации актуален для всех без исключения славянских языков, в том числе и для беспроблемных в настоящее время в коммуникативном отношении, и чреват вытеснением славянских языков на периферию внутринациональной коммуникации (в фольклорно-культурную сферу). Для новых стандартных славянских языков и языков, функционирующих в условиях близкородственного славянского двуязычия и многоязычия, эта тенденция затрудняет перспективы полноценного использования в важнейших сферах официального общения.

Bсе это также ставит перед славистикой XXI века новые вызовы и проблемы.

B-четвертых, подготовка и проведение XV Международного съезда славистов в Минске высветили и ряд актуальных вопросов организационного плана, связанных с:

a) необходимостью нахождения компромисса в вопросе сохранения традиций и поиска новых форм проведения международных съездов;

б) разграничением полномочий Международного и национальных комитетов славистов в формировании тематики и программы съездов;

в) уточнением компетенции национальных комитетов славистов и их роли в развитии и поддержании славистики прежде всего в собственных странах;

г) совершенствованием форм подготовки и презентации с учетом современных информационных возможностей материалов съездов до и после их проведения;

д) привлечением к участию в съездах молодых исследователей;

е) совершенствованием и оптимизацией форм работы съездов и места в программе тематических блоков, круглых столов и т.д.; 
ж) сохраниением уставного положения о проведении международных съездов славистов только в славянских странах и о рабочих языках съездов;

3) аккредитацией и оценкой деятельности комиссий при МКС и т.д.

Наконец, в-пятых, одним из важных итогов XV Международного съезда славистов в Минске стало решение пленума Международного комитета славистов о проведении XVI Международного съезда славистов в 2018 году в Сербии - славянской стране с богатыми славистическими традициями, внесшей огромный вклад в становление и развитие славистики как науки и проведение международных съездов славистов.

Таким образом, итоги XV Международного съезда славистов в Минске, а также достижение разумных компромиссов по всем названным научным и организационным вопросам даст возможность сохранить роль и значение славянских языков, литератур и культур в современном мире, будет способствовать расширению знаний о них в мире, позволит поддержать значение славистики как самостоятельного и актуального направления мировой филологической науки, поможет продолжить традиции проведения международных съездов славистов в XXI веке.

\section{ЛИТЕРАТУРА}

Аксамитов 1994: Аксамітаў, А.С., Малаш, Л.А., Даленга-Хадакоўскі Зарыян Якаўлевіч / А.С. Аксамітаў, Л.А. Малаш // Беларуская мова: Энцыкл./ Беларус. Энцыкл.; Пад рэд. А.Я. Міхневіча; Рэдкал.: Б.І. Сачанка (гал. рэд.) і інш. - Мн.: БелЭн, 1994. - С 173-174.

Булахов 1994: Булахаў, М.Г. „Беларусы” Я.Ф. Карскага /М.Г. Булахаў // Беларуская мова: Энцыкл./ Беларус. Энцыкл.; Пад рэд. А.Я. Міхневіча; Рэдкал.: Б.І. Сачанка (гал. рэд.) і інш. - Мн.: БелЭн, 1994. - С . 91-92.

Булахов 2013: Булахов, М.Г. „Слово о плъку Игореве” в переводах на славянские языки XIX-XX вв. / М.Г. Булахов. - Минск : Беларуская навука, 2013. $-360 \mathrm{c}$.

XV МЗС Беларуская... 2013: Беларуская мовазнаўчая славістыка на 3'ездах славістаў : Да XV Міжнароднага з’езда славістаў / Нац. акад. навук Беларусі, Беларус. нац. камітэт славістаў, Цэнтр даслед. беларус. культуры, мовы і літ-ры, Філіял „Ін-т мовы і літ-ры імя Я. Коласа і Я. Купалы”. - Мінск : Беларус. навука, 2013. - 483 с.

XV МЗС Замежная... 2013: Замежная мовазнаўчая беларусістыка на міжнародных з'ездах славістаў : зб. дакл. (да XV Міжнароднага з'езда славістаў) / уклад.. прадмова, камент. Г. А. Цыхуна ; Нац. акад. навук Беларусі, Цэнтр даслед. беларус. культуры, мовы і літ., філ. „Ін-т мовы і літ. імя Я. Коласа і Я. Купалы”. - Мінск : Беларус. навука, 2013. - 199 с. 
XV МЗС Праграма 2013: Праграма. XV Міжнародны з’езд славістаў. Мінск, Рэспубліка Беларусь, 20-27 жніўня 2013. - Мінск : Права і эканоміка, 2013. 104 C.

XV МЗС Тезисы-1 2013: XV Міжнародны з’езд славістаў = XV Международный съезд славистов $=$ XV International Congress of Slavists (Мінск, Беларусь, 20-27 жніўня 2013 г.) : тэзісы дакладаў. У 2 т. Т. 1. Мовазнаўства / рэдкал. : А.А. Лукашанец (гал. рэд.) [i інш.]. - Мінск : Беларус. навука, 2013. - $347 \mathrm{c}$.

XV МЗС Тезисы-2 2013: XV Міжнародны з'езд славістаў = XV Международный съезд славистов $=$ XV International Congress of Slavists (Мінск, Беларусь, 20-27 жніўня 2013 г.) : тэзісы дакладаў. У 2 т. Т. 2. Літаратуразнаўства. Культуралогія. Фалькларыстыка / рэдкал. : А.А. Лукашанец (гал. рэд.) [i інш.]. - Мінск : Беларус. навука, 2013. - 185 с.

Aleksandr Lukasanetz

\section{ORGANIZATION OF THE XV INTERNATIONAL CONGRESS OF SLAVISTS IN MINSK: RESULTS AND PROSPECTS OF THE WORLD SLAVIC STUDIES}

\section{Summary}

The purpose of the article - to reveal the cultural, historical and scientific background of the XV International Congress of Slavists in Minsk (Belarus 2013) and to describe its main outcomes. In particular, the article shows that the major historical and cultural prerequisites of the 2013 XV International Congress of Slavists in Minsk are: the status of Belarus as an independent Slavic country with long historic traditions of statehood; the existence of a separate literary Belarusian language and long written tradition; the unique experience of coexistence and interaction of the Belarusian language and Belarusian culture with other Slavic and non-Slavic languages and cultures; the specifics of the current language situation in the country - the state closely related Slavic Belarusian-Russian bilingualism. The scientific prerequisites for the Congress of Slavists in Belarus are: the significant contribution of Belarusian researchers in formation and development of the main directions of Slavic studies as a separate branch of philological sciences; the formation of a national Belarusian linguistics and Slavic studies; the active participation of the Belarusian researchers in international congresses of Slavists, in the activities of the commissions at the ICS and the development of major projects of modern Slavic studies; the preparation and publication of the fundamental works on Belorussian and Slavic studies in the second half of the XX - beginning of the XXI century, etc.

The main results of the Congress of Slavists in Minsk in the article include: the summarizing and discussion of the achievements of the world Slavic Studies in the previous five years; the preservation and maintenance of the traditions of international congresses of Slavists in the XXI century and the awareness of their importance for the development of contemporary Slavic studies; the need for understanding the new social and political conditions of life of the Slavic countries, and awareness of the phenomenon of expansion of the Slavic linguistic and cultural space; understanding of the importance of traditional scientific problems of Slavic studies and the need to change the priorities and expand the scientific perspective research in the field of the humanities; understanding of the urgent need to search for a reasonable compromise between the existing traditions and forms of organization of international congresses of Slavists and finding ways of their optimization and improvement, etc. One of the most important results is the decision to hold the next XVI International Congress of Slavists in 2018 in Serbia - a Slavic country with rich traditions of the Slavic studies.

Keywords: Slavic studies, International congresses of Slavists, language situation, bilingualism, Belorussian studies. 